\title{
Implementasi Kamera Termal pada Pemadam Api Otomatis
}

\author{
Albion Chastity dan Muhammad Rivai \\ Departemen Teknik Elektro, Institut Teknologi Sepuluh Nopember (ITS) \\ e-mail:muhammad_rivai@ee.its.ac.id
}

\begin{abstract}
Abstrak-Kebakaran adalah timbul dan membesarnya api secara tidak terkontrol yang menyebabkan kerusakan pada objek, struktur, dan lingkungan di sekitarnya. Instalasi pemadam api otomatis yang sering digunakan saat ini adalah sistem sprinkler menggunakan tabung kaca berisi cairan yang mudah memuai yang dipasang pada saluran air bertekanan atau tabung berisi bahan pemadam. Sistem ini memiliki kelemahan yaitu tidak adanya umpan balik sehingga akan terus mengeluarkan bahan pemadam hingga habis atau sumber air dimatikan. Penelitian ini bertujuan untuk menciptakan purwarupa sistem yang mengatasi kelemahan sistem pemadam api yang sudah ada. Sistem yang dirancang menggunakan sensor GRID-EYE AMG8833 dari Panasonic untuk mendeteksi api sebagai sinyal umpan-baliknya, Raspberry Pi sebagai sistem pemroses dan kontrol, sebuah relay, dan pompa air untuk memadamkan api. Hasil ekperimen menunjukkan bahwa dalam jarak 1 meter, alat ini dapat mendeteksi apakah suatu objek merupakan penyebab kebakaran dengan cara menghitung jumlah piksel objek terdeteksi yang memiliki nilai suhu $90^{\circ} \mathrm{C}$ yang dianggap sebagai api. Jika jumlah piksel melebihi 4 buah maka pompa akan dinyalakan untuk memadamkan api dan akan berhenti dengan sendirinya.
\end{abstract}

Kata Kunci-AMG8833, Kamera Termal, Kebakaran, Pemadam Api, Raspberry Pi.

\section{PENDAHULUAN}

K EBAKARAN menurut Kamus Besar Bahasa Indonesia adalah bahaya api atau terbakarnya sesuatu seperti rumah, hutan, dan lainnya. Kebakaran disebabkan oleh membesarnya api secara tidak terkendali sehingga menyebabkan kerusakan pada barang, struktur, atau lingkungan sekitar. Kebakaran yang sering terjadi disebabkan oleh kesalahan manusia seperti hubungan pendek atau korsleting aliran listrik dan kompor gas yang meledak. Guna mengatasi kebakaran yang terjadi perlu dibuat suatu alat yang dapat dengan cepat memadamkan api dengan efektif dan efisien.

Sistem pemadam api otomatis yang sering digunakan saat ini berupa penyemprot air bertekanan dengan sistem pasif menggunakan tabung berisi cairan yang mudah memuai. Cara kerja sistem mekanis tersebut adalah ketika suhu sekitar naik hingga batas tertentu, cairan di dalam tabung kaca akan memuai hingga memecahkan tabung kaca yang menahan sumbat dari pipa, pipa tersebut terhubung dengan saluran air yang bertekanan sehingga ketika sumbat terlepas, air akan menyembur ke sprinkler dan tersebar di area di mana panas terdeteksi [1].

Kelemahan utama sistem ini adalah tidak adanya umpan balik yang bisa digunakan untuk mendeteksi apakah api sudah padam atau belum sehingga sistem akan menyemprotkan bahan pemadam hingga habis atau sumber utama dimatikan. Hal ini mendasari suatu penelitian untuk merancang purwarupa sistem pemadam otomatis menggunakan kamera termal. Pilihan sensor yang digunakan dalam penelitian ini adalah Panasonic GRID-EYE AMG8833 yang merupakan sensor panas berjenis thermopile array karena merupakan salah satu sensor kamera termal yang murah dan mudah didapat. Penelitian ini diharapkan bisa membantu dalam pengembangan alat pemadam api otomatis sebagai alternatif dari teknologi yang sudah ada.

\section{TEORI PENUNJANG}

\section{A. Defenisi Kebakaran}

Menurut KBBI, arti kata kebakaran adalah (1) peristiwa terbakarnya sesuatu, (2) menderita karena terbakar, (3) bahaya api. Menurut kamus Oxford, kebakaran adalah api yang tidak terkontrol dan menghancurkan bangunan, pepohonan, dan sebagainya. Kebakaran adalah bencana yang disebabkan oleh timbul dan membesarnya api secara tidak terkontrol sehingga menyebabkan kerusakan pada benda, struktur, dan lingkungan di sekitarnya. Dari definisi ini dapat digunakan sebagai parameter untuk menentukan apakah sumber panas yang dideteksi alat bisa dianggap sebagai suatu kebakaran.

\section{B. Radiasi Benda Hitam}

Secara teori, benda-benda yang memiliki suhu di atas $0^{\circ} \mathrm{K}$ atau $-273^{\circ} \mathrm{C}$ dapat memancarkan radiasi elektromagnetik [2]. Radiasi tersebut mewakili perubahan energi panas benda menjadi energi elektromagnetik. Hal tersebut dikenal sebagai radiasi panas. Radiasi benda hitam merupakan radiasi panas yang dilepaskan secara spontan oleh kebanyakan benda. Benda hitam merupakan sebutan terhadap benda yang menyerap semua radiasi elektromagnetik yang datang di semua panjang gelombang. Radiasi benda hitam adalah radiasi elektromagnetik yang dipancarkan oleh benda ketika kesetimbangan termal benda tersebut berada pada suhu yang konstan dan seragam [3]. Dalam kondisi tersebut, radiasi yang dipancarkan benda hitam hanya bergantung pada suhu atau temperatur benda hitam tersebut. Radiasi panjang gelombang elektromagnetik benda hitam per unit panjang gelombang pada temperatur equilibrium $\mathrm{T}$ dapat dihitung menggunakan hukum Planck dengan rumus:

$$
L_{\lambda}=\frac{2 h c^{2}}{\lambda^{5}} \frac{1}{e^{h c / \lambda k T}-1}
$$

h merupakan konstanta Planck $6,62606896 \times 10^{-34} \mathrm{Js}$, c merupakan konstanta kecepatan cahaya dalam vakum $299.792 .458 \mathrm{~m} / \mathrm{s}, \lambda$ merupakan panjang gelombang dalam 


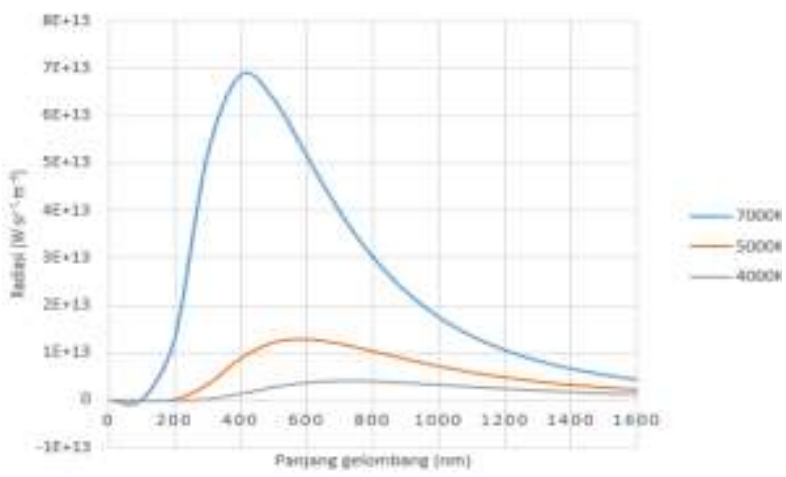

Gambar 1. Radiasi spektrum benda hitam sesuai hukum Planck

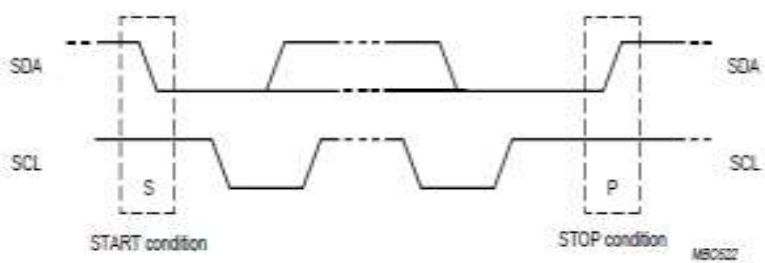

Gambar 2. Sinyal start dan stop pada $\mathrm{I}^{2} \mathrm{C}$

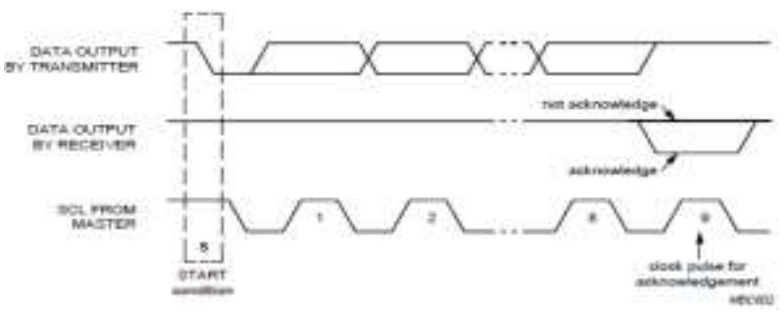

Gambar 3. Sinyal ACK pada I2C

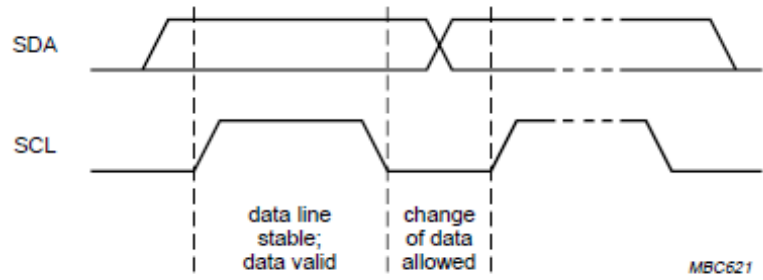

Gambar 4. Sinyal data dan perubahan bit pada $\mathrm{I}^{2} \mathrm{C}$

meter, $\mathrm{k}$ adalah konstanta Boltzmann $1,380649 \times 10^{-23} \mathrm{~J} \cdot \mathrm{K}^{-1}$, dan $\mathrm{T}$ adalah temperatur dalam Kelvin (K). Hasil dari hukum Planck tersebut adalah daya yang diemisikan per area per panjang gelombang yang merupakan fungsi dari $\lambda$ dan $T$. Gambar 1 menunjukkan distribusi radiasi elektromagnetik yang dipancarkan oleh benda hitam dalam temperatur yang berbeda. Besar energi yang dipancarkan pada tiap panjang gelombang ditunjukkan oleh kurva tersebut. Dapat dilihat bahwa benda hitam memancarkan radiasi pada seluruh panjang gelombang tetapi memiliki intensitas yang berbeda dan terdapat beberapa panjang gelombang tertentu yang memiliki intensitas paling tinggi dibandingkan yang lain dalam temperatur yang sama. Secara garis besar, total daya radiasi menjadi semakin tinggi sebanding dengan suhu benda hitam. Daya total dari radiasi benda hitam pada suatu temperatur stabil dapat dicari dengan menggunakan persamaan Stefan-Boltzmann

$$
P=\sigma T^{4}
$$

$\mathrm{P}$ adalah total energi yang dipancarkan benda hitam per unit

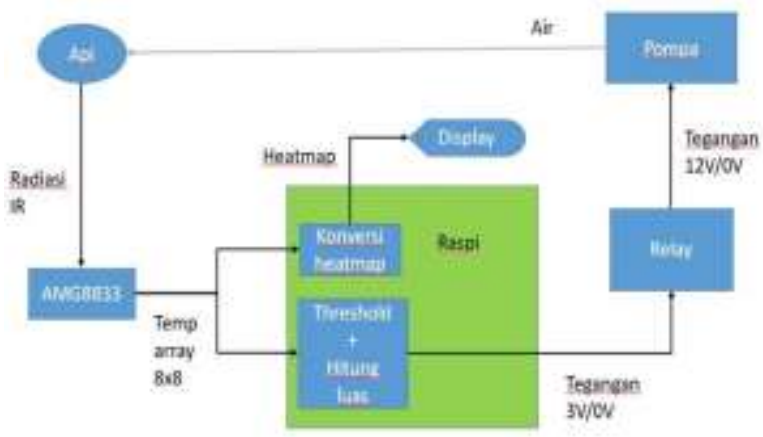

Gambar 5. Diagram cara kerja alat

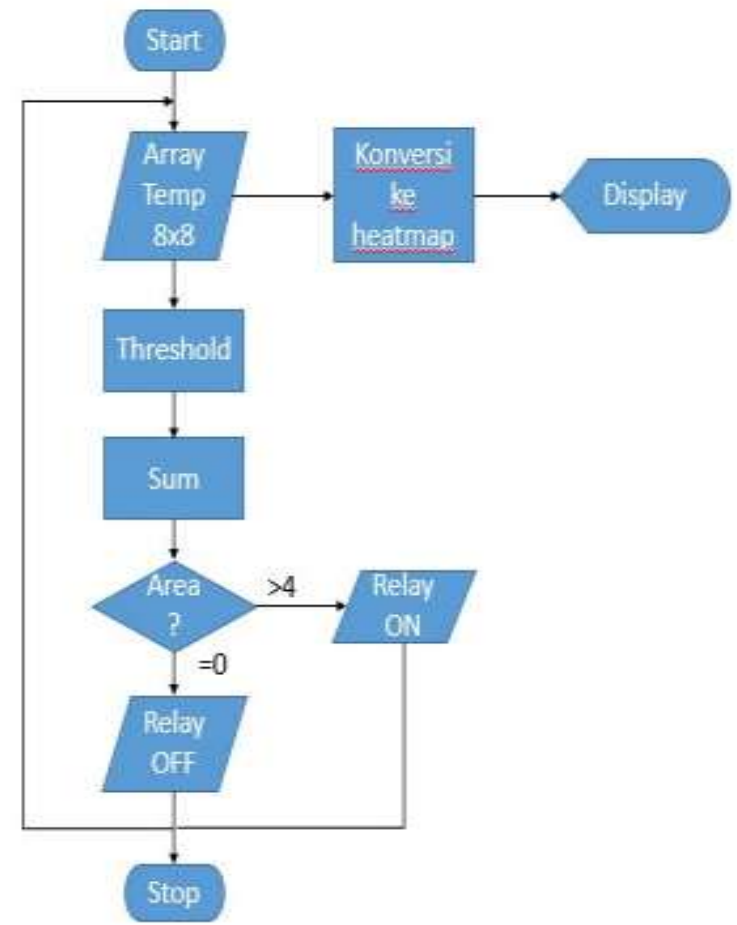

Gambar 6. Diagram flowchart program.

area permukaan per unit waktu di semua panjang gelombang, $\sigma$ adalah konstanta Stefan-Boltzmann 5,67040 $\times 10^{-8}$ $\mathrm{W} / \mathrm{m}^{2} \mathrm{~K}^{4}$, dan $\mathrm{T}$ adalah temperatur dalam Kelvin (K) [4]. Puncak panjang gelombang untuk suatu temperatur tertentu dapat dihitung menggunakan hukum Wien yang menjelaskan bahwa panjang gelombang pada intensitas maksimum akan bergeser ke panjang gelombang yang lebih pendek apabila suhunya semakin meningkat. Pernyataan tersebut dapat dituliskan dalam rumus:

$$
\lambda_{\max }=\frac{C}{T}
$$

$\lambda_{\max }$ merupakan panjang gelombang intensitas maksimum dalam meter, $\mathrm{C}$ adalah konstanta pergeseran Wien sebesar $2.9 \times 10^{-3} \mathrm{mK}$, dan T adalah suhu dalam Kelvin (K). Gambar 1 menunjukkan hubungan intensitas radiasi benda hitam terhadap panjang gelombang pada suhu yang berbeda. Dapat dilihat bahwa ketika suhu benda hitam meningkat, panjang gelombang untuk intensitas maksimum $\left(\lambda_{\text {maks }}\right)$ bergeser ke nilai panjang gelombang yang lebih pendek.

\section{Kamera Termal}

Kamera termal merupakan suatu device yang membentuk gambar dari pancaran radiasi panas sebuah benda. Salah satu alat pengukur radiasi inframerah yang paling sederhana 


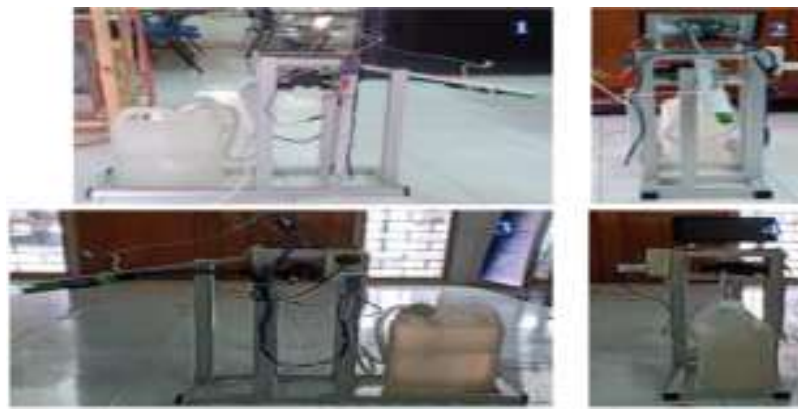

Gambar 7. Purwarupa alat tampak kanan (1), depan (2), kiri (3), dan belakang (4).

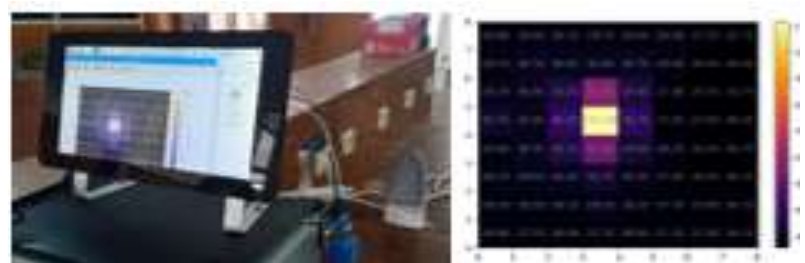

Gambar 8. Pengujian sensor dengan objek setrika.
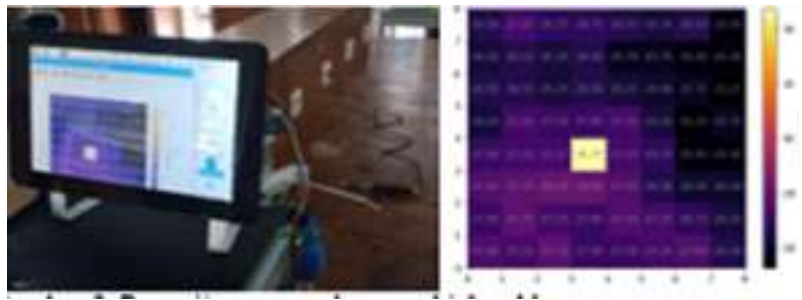

Gambar 9. Pengujian sensor dengan objek solder.
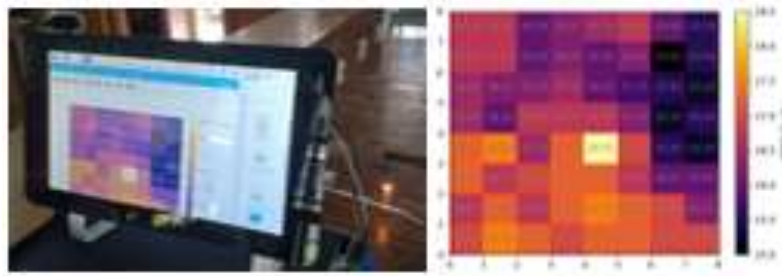

Gambar 10. Pengujian sensor dengan objek lilin.

adalah sebuah pyrometer dimana alat tersebut menghasilkan luaran yang menggunakan sebuah sensor tunggal. Sedangkan alat yang lebih canggih biasanya menggunakan banyak sensor (sensor array) yang mampu menghasilkan informasi yang lebih detail [4], [5]. Pancaran radiasi oleh benda akan diubah menjadi sinyal elektronik untuk memperoleh gambar yang dapat dilihat dengan mata [6][7]. Gambar dari kamera termal akan diubah ke gambar yang bisa kita lihat dengan menetapkan warna pada setiap pancaran energi inframerah. Gambar tersebut biasa disebut dengan thermogram. Perbedaan dari kamera termal dengan kamera biasa adalah pada kamera biasa, gambar yang didapatkan merupakan pantulan dari cahaya ke objek sedangkan pada kamera termal, gambar yang didapatkan merupakan representasi pancaran radiasi dari objek. Hal ini menyebabkan kamera termal mampu bekerja tanpa adanya sumber cahaya tampak. Kamera termal memiliki 2 jenis yaitu cooled detector dan uncooled detector [8]. Secara umum, kamera termal memiliki cara kerja sebagai berikut: (1)Benda memancarkan radiasi inframerah; (2)Lensa menangkap dan memfokuskan sinar inframerah ke detektor inframerah; (3)Detektor meneruskan data ke elektronik sensor; (4)Sensor akan merubah data yang diterima dari detektor menjadi citra dan ditampilkan dalam
Tabel 1.

Pengujian objek panas setrika

\begin{tabular}{lll}
\hline \hline \multirow{2}{*}{ Posisi } & \multicolumn{2}{c}{ Temperatur $\left({ }^{\circ} \mathrm{C}\right)$} \\
& Objek & Sekitar \\
\hline 1 piksel & 115,5 & $34-57$ \\
Antara 2 piksel & $79,5-81,5$ & $41-48$ \\
Antara 4 piksel & $54-57$ & $29-31$ \\
\hline \hline
\end{tabular}

Tabel 2.

Pengujian objek panas solder

\begin{tabular}{lll}
\hline \hline \multirow{2}{*}{ Posisi } & \multicolumn{2}{c}{ Temperatur $\left({ }^{\circ} \mathrm{C}\right)$} \\
& Objek & Sekitar \\
\hline 1 piksel & 34,75 & $27-28$ \\
Antara 2 piksel & $30-32$ & $26,5-27,5$ \\
Antara 4 piksel & $27,75-28,5$ & $25,5-27$ \\
\hline \hline
\end{tabular}

Tabel 3.

Pengujian objek panas lilin.

\begin{tabular}{lll}
\hline \hline \multirow{2}{*}{ Posisi } & \multicolumn{2}{c}{ Temperatur $\left({ }^{\circ} \mathrm{C}\right)$} \\
& Objek & Sekitar \\
\hline 1 piksel & 28,5 & $26,25-27,25$ \\
Antara 2 piksel & $27,5-28$ & $25,75-27$ \\
Antara 4 piksel & $26,25-27$ & $25,5-26,5$ \\
\hline \hline
\end{tabular}

Tabel 4.

Pengujian simulasi kebakaran

\begin{tabular}{llll}
\multicolumn{4}{c}{ Pengujian simulasi kebakaran } \\
\hline \hline Progress api & Piksel $>90^{\circ} \mathrm{C}$ & \multicolumn{2}{c}{ Temperatur $\left({ }^{\circ} \mathrm{C}\right)$} \\
& & Sumber & Api \\
\hline Baru tersulut & 1 & 108 & $70-78$ \\
Mulai membesar & $\geq 4$ & 334 & $80-111$ \\
Besar & $>4$ & 334 & $95-116$ \\
\hline \hline
\end{tabular}

display. Beberapa keunggulan utama dari kamera termal antara lain; (a)Perangkat tidak bersentuhan dengan objek sehingga dapat digunakan untuk mengukur suhu benda berbahaya; (b)Hasil gambar dua dimensi dari perangkat dapat diolah untuk berbagai kepentingan dan analisa; (c)Perangkat dapat mengukur benda diam dan bergerak secara real time.; (d)Perangkat tidak memiliki efek radiasi berbahaya seperti $X$ ray imaging sehingga dapat digunakan dalam jangka waktu yang lama; $€$ Perangkat tidak mempengaruhi objek.

\section{D. $A M G 8833$}

Sensor AMG88XY adalah sebuah thermopile infrared array sensor yang menggunakan teknologi MEMS (Micro Electro Mechanical System) buatan Panasonic. Sensor tersebut terdiri atas 64 buah thermopile, detektor inframerah pasif yang terdiri dari thermocouple yang dirangkai seri/paralel dan disusun secara dua dimensi [9][10][11], dan masing-masing thermopile mewakili 1 piksel. AMG88XY memiliki beberapa jenis tipe sensor yaitu tergantung dua digit terakhir X dan Y. Digit 88 menunjukkan resolusi sensor yaitu 8 piksel horizontal $\times 8$ piksel vertikal. Digit $X$ menunjukkan tegangan suplai sensor, 3 adalah 3,3V dan 5 adalah 5V. Digit Y menunjukkan jenis gain, 3 adalah high gain dan 4 adalah low gain [12]. Pada penelitian ini akan digunakan jenis sensor bertipe AMG8833. Sensor tersebut merupakan jenis infrared array sensor yang berjumlah total 64 piksel dengan kemampuan mendeteksi $0^{\circ} \mathrm{C}$ hingga $80^{\circ} \mathrm{C}$ dengan toleransi pembacaan $\pm 2,5^{\circ} \mathrm{C}$. Sensor dapat beroperasi pada tegangan sebesar 3,3VDC dengan batas toleransi $\pm 0,3$ VDC. Sensor tersebut dapat mendeteksi objek dengan jarak maksimal 5 meter dengan viewing angle sebesar $60^{\circ}$. Sensor ini secara standar bekerja dengan kecepatan 10 fps dan memiliki dua kali moving average. Pada sensor ini juga terdapat thermistor 

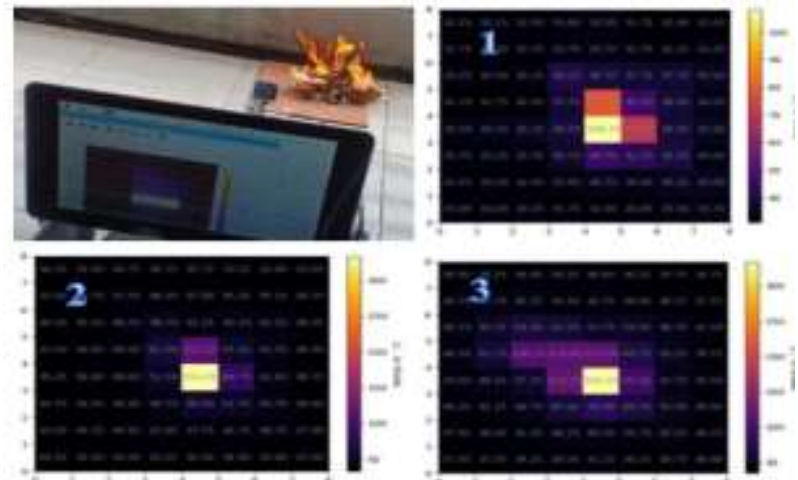

Gambar 11. Pengujian sensor dengan simulasi kebakaran (1), api baru tersulut (2), api membesar (3), api besar (4).

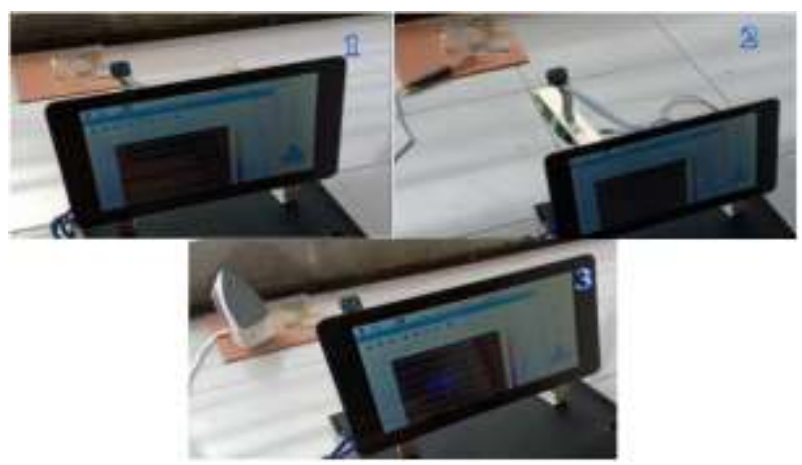

Gambar 12. Pengujian respon alat terhadap lilin (1), solder (2), dan setrika (3).

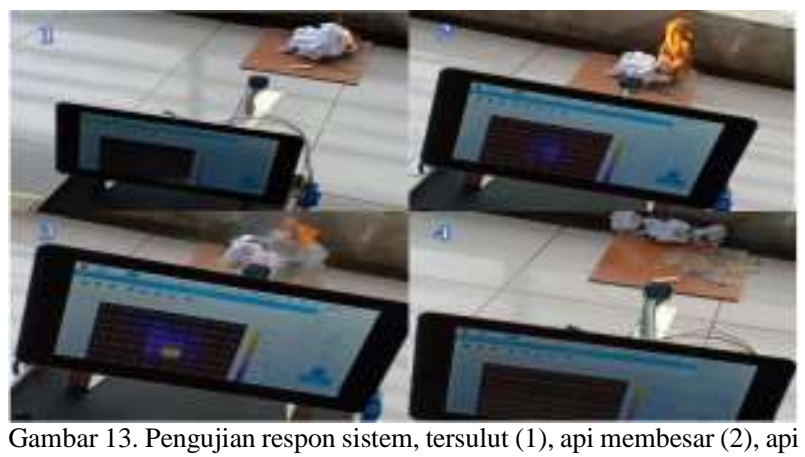

Gambar 13. Pengujian respon sistem, tersulut (1), api membesar
besar dan pompa menyala (3), api padam dan pompa mati (4).

untuk mengukur suhu lingkungan dan juga sebagai referensi dari bacaan thermopile [11].

\section{E. Raspberry Pi 3 Model B}

Raspberry Pi 3 Model B adalah single board computer sebesar kartu kredit berbasis arsitektur ARM yang dikembangkan oleh organisasi nirlaba Raspberry Pi Foundation yang berbasis di Inggris [[13][14][15]. Raspberry Pi 3 Model B adalah generasi ketiga dari salah satu varian produk Raspberry Pi. Modul ini menggunakan chipset BCM2837 sebagai cpu dan memiliki RAM 1 GB. Produk ini memiliki 40-pin GPIO dengan kemampuan komunikasi serial (UART, I ${ }^{2} \mathrm{C}$, SPI), dan PWM. Tegangan operasi I/O GPIO adalah $3,3 \mathrm{~V}[16]$.

\section{F. Komunikasi I2C}

Sesuai namanya, komunikasi $\mathrm{I}^{2} \mathrm{C}$ (Inter-Integrated Circuit) merupakan suatu protokol komunikasi yang dibuat sebagai media komunikasi antara perangkat-perangkat terintegrasi
Tabel 5.

Pengujian modul relay

\begin{tabular}{|c|c|c|c|c|}
\hline \multirow{2}{*}{ GPIO } & \multicolumn{4}{|c|}{ Relay } \\
\hline & Vec & Vin & Port NO & Port NC \\
\hline Low & \multirow{2}{*}{$5 \mathrm{~V}$} & $0 \mathrm{~V}$ & Terbuka & Tertutup \\
\hline High & & $3 \mathrm{~V}$ & Tertutup & Terbuka \\
\hline \multicolumn{5}{|c|}{$\begin{array}{c}\text { Tabel } 6 \text {. } \\
\text { Pengujian power supply dan pompa }\end{array}$} \\
\hline \multirow{2}{*}{ Beban } & \multicolumn{4}{|c|}{ Power Supply \& Pompa } \\
\hline & & V pompa & V supply & $\mathrm{I}$ \\
\hline Open & & - & $12 \mathrm{~V}$ & - \\
\hline Rendah & \multicolumn{3}{|c|}{$11,6 \mathrm{~V}$} & $0,42 \mathrm{~A}$ \\
\hline Tinggi & \multicolumn{3}{|c|}{$11,8 \mathrm{~V}$} & $1,44 \mathrm{~A}$ \\
\hline Short & & - & - & $0 \mathrm{~A}$ \\
\hline
\end{tabular}

Tabel 7.

Pengujian respon alat terhadap berbagai objek

\begin{tabular}{cc}
\hline \hline Sumber panas & Pompa \\
\hline Setrika & Tidak \\
Solder & Tidak \\
Lilin & Tidak \\
Kertas (simulasi) & Menyala \\
\hline \hline
\end{tabular}

Tabel 8 .

Pengujian respon alat pada simulasi kebakaran

\begin{tabular}{lll}
\hline \hline Progress api & Area & Pompa \\
\hline Baru tersulut & $\leq 1$ piksel & mati \\
Mulai membesar & $\leq 4$ piksel & mati \\
Besar & $>4$ piksel & nyala \\
Padam & 0 piksel & mati \\
\hline \hline
\end{tabular}

seperti sensor, EEPROM, RTC, dan lain sebagainya. $\mathrm{I}^{2} \mathrm{C}$ bersifat synchronous karena terdapat clock yang menyamakan ketukan antara pengirim dan penerima. $\mathrm{I}^{2} \mathrm{C}$ menggunakan two-wire interface yaitu pin SDA (Serial Data) dan SCL (Serial Clock). Perangkat yang menggunakan komunikasi $\mathrm{I}^{2} \mathrm{C}$ memiliki alamat sebesar 1-byte yang terdiri dari 7-bit alamat dan 1-bit perintah R/W (Read/Write). Pada pin SDA dan SCL perlu diberikan resistor pull-up karena bersifat open drain. Pada komunikasi $\mathrm{I}^{2} \mathrm{C}$ ada yang bertindak sebagai master dan slave. Master merupakan perangkat yang menghasilkan sinyal clock, start, dan stop. Sedangkan slave merupakan perangkat yang dialamatkan oleh master. Pada komunikasi $\mathrm{I}^{2} \mathrm{C}$ terdapat beberapa sinyal yaitu, sinyal start, data, ACK, dan stop. Sinyal start adalah sinyal yang dipergunakan untuk memulai komunikasi, ditandai dengan kondisi SDA berubah dari HIGH ke LOW ketika SCL dalam kondisi HIGH. Sinyal stop merupakan sinyal untuk mengakhiri komunikasi, ditandai dengan kondisi SDA dari LOW ke HIGH ketika SCL dalam kondisi HIGH seperti yang ditunjukkan pada Gambar 2.

Setiap receiver wajib mengirimkan sinyal ACK atau sinyal balasan setiap selesai pengiriman 1-byte atau 8-bit data. Saat itu, master harus memberikan clock tambahan pada SCL, yaitu clock kesembilan untuk memberikan kesempatan receiver mengirimkan sinyal ACK ke transmitter berupa keadaan LOW pada SDA selama SCL dalam kondisi HIGH, ditunjukkan pada Gambar 3. Pada proses transfer data, keadaan data SDA harus stabil dan kondisi SCL harus dalam keadaan HIGH. Sedangkan jika akan melakukan perubahan data, hanya dapat dilakukan ketika SCL dalam kondisi LOW. Jika terjadi perubahan data ketika SCL dalam kondisi HIGH, maka hal tersebut bisa dianggap sinyal start atau stop seperti yang ditunjukkan pada Gambar 4. 


\section{PERANCANGAN SISTEM}

Pemadam api otomatis yang dibuat pada penelitian ini secara umum terdiri dari kamera termal, single board computer Raspberri Pi 3 Model B, sebuah modul relay, sebuah pompa dc. Kamera termal digunakan untuk mendeteksi keberadaan dan besar api. Single board computer digunakan untuk mengakses kamera termal dan memproses data untuk ditampilkan sebagai heatmap dan menentukan apakah data yang dibaca berupa api dan menentukan apakah akan menyalakan relay atau tidak. Relay berfungsi untuk driver pompa dc 12V. Pompa digunakan untuk menyemprotkan air untuk memadamkan api, ditunjukkan pada Gambar 5. Kamera termal yang digunakan bertipe AMG8833 yang merupakan sensor buatan Panasonic. Single board computer yang digunakan adalah Raspberry Pi 3 Model B. Driver berupa relay dan aktuator berupa pompa DC merk Taffware model DP-537.

Cara kerja dari pemadam api otomatis secara singkat sebagai berikut. Kamera termal akan mendeteksi keberadaan api dengan mendeteksi panas atau suhunya. Lalu dilakukan proses segmentasi menurut intensitas yang disebut thresholding[17]. Selanjutnya single board computer akan menentukan besar api yang terdeteksi berdasarkan data suhu yang diperoleh dari kamera termal. Jika besar api melebihi batas tertentu, single board computer akan mengaktifkan relay untuk menjalankan pompa. Api akan mengecil karena disemprot dengan air hingga padam dan hasil bacaan suhu oleh kamera termal akan menurun hingga tidak ada piksel yang lebih tinggi daripada threshold.

Cara kerja program sesuai dengan flowchart pada Gambar 6. Pertama, program membaca sensor AMG8833 untuk mendapatkan data array temperatur berukuran $8 \times 8$. Setelah itu, ada dua hal yang dilakukan, menampilkan display dengan mengonversi array temperatur ke heatmap, dan memproses array untuk menentukan kebakaran dengan men-threshold biner array dan mencari luasan dengan menjumlah hasil threshold biner. Kemudian diambil keputusan untuk menyalakan relay berdasarkan luasan yang di dapat. Jika luasan melebihi 4 piksel, maka relay akan dinyalakan, dan bila luasan bernilai 0 , maka relay akan dimatikan. Proses ini diulang terus-menerus hingga program dimatikan secara manual.

\section{PENGUJIAN DAN ANALISIS}

\section{A. Pengujian AMG8833}

Purwarupa alat yang digunakan dalam penelitian ini ditunjukkan pada Gambar 7. Pengujian dilakukan untuk mengetahui nilai threshold yang bisa digunakan dalam menentukan apakah objek yang terdeteksi oleh sensor merupakan api agar sistem tidak terpicu ketika mendeteksi benda panas selain api. Pengujian dilakukan dengan menaruh tiga macam sumber panas, yaitu setrika, solder, dan lilin dengan jarak sekitar 1 meter di posisi di mana sensor mendeteksi benda hanya di 1 piksel, interseksi antara 2 piksel, dan interseksi antara 4 piksel. Akuisisi data heatmap dalam bentuk citra dengan format .png dilakukan dengan fungsi matplotlib.pyplot.savefig().

Pengujian dilakukan dengan sumber panas berupa setrika, solder, dan api lilin, ditunjukkan pada Gambar 8, 9, dan 10. Berdasarkan hasil pengujian, posisi sumber panas yang terdeteksi relatif terhadap piksel sangat berpengaruh pada bacaan temperatur di mana temperatur terbaca paling tinggi ketika objek berada dalam 1 piksel dan semakin menurun dengan jumlah piksel yang berinterseksi, ditunjukkan pada Tabel 1, 2, dan 3. Besar penampang sumber panas juga berpengaruh terhadap bacaan suhu, di mana api lilin memiliki perbedaan temperatur yang sangat kecil dibandingkan suhu ruangan sehingga sulit terdeteksi dan temperatur solder terbaca lebih rendah dari setrika karena penampang yang jauh lebih kecil.

Pada simulasi kebakaran dengan kertas pada Gambar 11, dapat dilihat perkembangan besarnya api dengan pusat api memiliki temperatur jauh lebih tinggi dari sekitarnya. Temperatur pusat api dapat mencapai lebih dari $300^{\circ} \mathrm{C}$. Sedangkan temperatur api tepi berkisar antara $100^{\circ} \mathrm{C}$ hingga $120^{\circ} \mathrm{C}$ yang ditunjukkan pada Tabel 4. Dari kumpulan data bisa disimpulkan bahwa parameter temperature threshold sedikit di bawah api tepi sebesar $90^{\circ} \mathrm{C}$ dan luas area minimal 5 piksel untuk pemicunya.

\section{B. Pengujian Modul Relay}

Modul Relay yang digunakan pada percobaan ini adalah modul relay $5 \mathrm{~V}$ yang menggunakan sumber tegangan $5 \mathrm{~V}$ dan dapat dipicu dengan tegangan $3,3 \mathrm{~V}$ yang mana merupakan tegangan output dari GPIO Raspberry Pi 3. Di sisi switch, modul relay ini memiliki kapasitas 250VAC/10A, 125VAC/15A, dan 40VDC/10A. Tujuan pengujian modul adalah untuk memastikan bahwa modul bekerja sesuai harapan dengan input trigger hanya 3,3V. Berdasarkan hasil pengujian pada Tabel 5 , modul relay dapat bekerja dengan baik dengan pengaturan yang digunakan yaitu $5 \mathrm{~V} \mathrm{Vcc}$ dengan input pemicu GPIO raspberry pi yang hanya sebesar $3 \mathrm{~V}$.

\section{Pengujian Pompa dan Power Supply}

Pompa yang digunakan adalah pompa DC merk Taffware model DP - 537 dengan spesifikasi input tegangan $12 \mathrm{~V}$, tekanan 0,68MPa, debit 4,0L/menit, dan daya maksimum 60 - $65 \mathrm{~W}$, dan memiliki fitur keamanan dimana pompa akan mati otomatis ketika tekanan dalam saluran mencapai 100 PSI. Power supply yang digunakan adalah modul power supply 12V/5A. Tujuan pengujian ini adalah untuk memastikan bahwa power supply yang digunakan dapat memenuhi konsumsi daya dari pompa bahkan ketika bekerja maksimal. Hasil pengujian pada Tabel 6 menunjukkan bahwa power supply dan pompa bekerja dengan baik dan pompa tidak menarik arus melebihi kapasitas power supply yaitu 5A.

\section{Pengujian Perangkat Lunak dan Keseluruhan Sistem}

Pengujian perangkat lunak dan sistem secara keseluruhan dilakukan untuk mengetahui performa sistem yang meliputi kemampuan untuk membedakan antara kebakaran dan objek panas lain dan apakah sistem akan terpicu ketika mendeteksi sumber api kecil seperti lilin. Pengujian dilakukan dengan menempatkan 4 macam sumber panas secara bergantian dengan jarak sekitar 1 meter dari alat. Dapat dilihat pada Gambar 12 dan Tabel 7 bahwa purwarupa tidak terpicu oleh benda panas yang terkontrol yang tidak sesuai dengan definisi kebakaran. Gambar 13 dan Tabel 8 menunjukkan bahwa alat ini juga dapat berhenti secara otomatis ketika api sudah padam. 


\section{KESIMPULAN}

Pada studi ini telah dibuat sebuah purwarupa sistem pemadam api menggunakan kamera termal GRID-EYE AMG8833 dan single board computer Raspberry Pi sebagai sistem pemroses kontrol pompa air untuk memadamkan api. Hasil percobaan menunjukkan bahwa kamera termal dapat mendeteksi objek panas dalam jarak 1 meter. Temperatur pusat api dapat mencapai lebih dari $300^{\circ} \mathrm{C}$. Sedangkan temperatur api tepi berkisar antara $100^{\circ} \mathrm{C}$ hingga $120^{\circ} \mathrm{C}$. Besarnya suhu ini dijadikan parameter threshold dengan luas area minimal 5 piksel untuk pemicunya. Alat bekerja sesuai parameter yang telah ditentukan dan tidak terpicu ketika mendeteksi objek selain api dengan suhu tinggi dan api kecil seperti lilin yang merupakan api terkontrol. Hasil penelitian ini diharapkan bisa membantu dalam pengembangan alat pemadam api otomatis sebagai alternatif dari teknologi yang sudah ada.

\section{DAFTAR PUSTAKA}

[1] "How Do Fire Sprinklers Work.".

[2] M. F. Modest, Radiative Heat Transfer. Elsevier Inc., 2013.

[3] E. Tola, "Black-Body SNR Formulation of Astronomical Camera Systems," IEEE Sens. J., vol. 15, no. 9, pp. 4941-4949, Sep. 2015.

[4] R. Usamentiaga, P. Venegas, J. Guerediaga, L. Vega, J. Molleda, and F. G. Bulnes, "Infrared Thermography for Temperature Measurement and Non-Destructive Testing," Sensors (Switzerland), vol. 14, no. 7, pp. 12305-12348, 2014.

[5] M. Husni, D. O. Siahaan, H. T. Ciptaningtyas, H. Studiawan, and Y. P. Aliarham, "Liquid volume monitoring based on ultrasonic sensor and Arduino microcontroller," in IOP Conference Series: Materials Science and Engineering, 2016, vol. 128, no. 1.

[6] M. Tasumi and A. Sakamoto, Introduction to Experimental Infrared Spectroscopy : Fundamentals and Practical Methods. .

"Temperature Guns Vs Thermal Imaging Technology." .

[7] "Temperature Guns Vs Thermal Imaging

[9] S. Saito and H. Nishi, "Practical Estimation Method of Thermal Sensation Using an Infrared Array Sensor," Dec-2019. .

[10] J. Tanaka, M. Shiozaki, F. Aita, T. Seki, and M. Oba, "Thermopile Infrared Array Sensor for Human Detector Application," in Proceedings of the IEEE International Conference on Micro Electro Mechanical Systems (MEMS), 2014, pp. 1213-1216.

[11] W. Y. Samsudin and M. Rivai, "Sistem Pemetaan Suhu Permukaan Lahan Menggunakan Sensor Inframerah untuk Pendeteksi Dini Kebakaran,” Tekik, vol. 7, no. 1, pp. 193-198, 2018.

[12] Panasonic, "Datasheet Infrared Array Sensor GRID-EYE (AMG88), Panasoni," Datasheet, 2016.

[13] N. A. Syahid, M. Rivai, and S. Suwito, "Sistem Keamanan pada Lingkungan Pondok Pesantren Menggunakan Raspberry Pi," $J$. Tek. ITS, vol. 5, no. 2, pp. A331-A335, Sep. 2016.

[14] D. J. Megatarini and Y. Everhard, "Sistem Kontrol dan Monitoring Kadar Amonia untuk Budidaya Ikan yang Diimplementasi pada Raspberry Pi 3B," Skanika, vol. 1, no. 2, pp. 374-A379, 2018.

[15] A. H. Yesa and M. Rivai, "Otomatisasi Pelayanan Binatu Berbasis Raspberry Pi Untuk Meningkatkan Efektivitas Dan Efisiensi Kegiatan Operasional Dan Pelayanan Binatu," J. Tek. ITS, vol. 5, no. 2, pp. 225-230, 2016.

[16] "Raspberry Pi 3 Model B.".

[17] D. Krisrenanto, M. Rivai, and F. Budiman, "Identifikasi Jumlah dan Tingkat Aktivitas Orang Berbasis Pengolahan Citra Menggunakan Raspberry Pi," J. Tek. ITS, vol. 6, no. 1, pp. 105109, Mar. 2017. 